\title{
Going for Broke: A Talk to Music Teachers
}

\author{
Juliet Hess \\ Michigan State University, USA
}

\author{
Brent C. Talbot \\ Gettysburg College, USA
}

In 1963-a racially-charged time in the United States-James Baldwin delivered "A Talk to Teachers," urging educators to engage youth in difficult conversations about current events. We concur with Giroux $(2011,2019)$ that political forces influence our educational spaces and that classrooms should not be viewed as apolitical, but instead seen as sites for engagement, where educators and artists alike can "go for broke." Drawing upon A Tribe Called Quest's 2017 Grammy performance of "We the People..." as an example of the role of the arts in troubled times, we consider ways to work alongside youth in schools to respond, consider, and process current events through music.

Keywords: James Baldwin, A Tribe Called Quest, activism, music education, social change

Let's begin by saying that we are living through a very dangerous time... The societ[ies] in which we live [are] desperately menaced, not by [outside forces], but from within. To any citizen ... who figures [one]self as responsible-and particularly those of [us] who deal with the minds and hearts of young people-must be prepared to "go for broke." Or to put it another way, [we] must understand that in the attempt to correct so many generations of bad faith and cruelty, when it is operating not only in the classroom but in society, [we] will meet the most fantastic, the most brutal, and the most determined resistance. There is no point in pretending that this won't happen. (Baldwin $1998,678)^{1}$

On October 16, 1963-a contentious time in the United States in regards to race and social stratification-Black scholar, novelist, social critic, and activist James Baldwin delivered "A Talk to Teachers." In May of that year, 4,000 African American elementary and secondary school students from across the country traveled to Birmingham, Alabama, to protest racial segregation, targeting public 
facilities, restaurants, and stores. The next month, Medgar Evers, leading civilrights activist and state field director of the National Association for the Advancement of Colored People (NAACP) was murdered in his driveway in Jackson, Mississippi, by White supremacist Byron De La Beckwith Sr. Beckwith was subsequently tried twice on the charges; both trials resulted in hung juries. In late August, the famous March on Washington took place; in September, members of the White supremacist organization, the Ku Klux Klan (KKK), planted dynamite attached to a timing device beneath the steps on the east side of the Sixteenth Street Baptist Church in Birmingham, Alabama, killing four young girls (Veterans of the Civil Rights Movement 2018).

We continue to live in "dangerous times." The staggering number of executive orders and legislative moves since Trump's January 2017 inauguration continue to foster a climate of precarity, uncertainty, and extreme stress for many people in the United States-particularly people of color, women, immigrants, the LGBTQ community, groups in lower socioeconomic classes, and people with disabilities. Moves such as the "Muslim Ban" (Panduranga, Patel, and Price 2017) and the uncertainty of Deferred Action for Childhood Arrivals (DACA) (Lind, Scheltens, and Philbrick 2017; Wilson 2017) have left specific populations particularly vulnerable. The discourse and action about repealing the Affordable Care Act (Rovner 2018) threaten to leave many Americans without healthcare. ${ }^{2}$ The election of Donald J. Trump in November 2016 emboldened White supremacists. On August 12, 2017, in Charlottesville, Virginia, for example, White supremacists openly demonstrated with swastikas, shouting racial and anti-Semitic slurs. Counter-protesters of this "Unite the Right" rally resisted peacefully, and the nation watched as James Alex Fields Jr. drove his car into the crowd of counterprotesters, killing Heather Heyer and injuring 28 others. The White supremacist group demonstrated publicly, without the hoods or coverings organizations such as the KKK have used in the past to shield their identities (Marcolini and Decker 2017; Charlottesville: Race and Terror 2017). Indeed, this unmasked demonstration seems to indicate that calling oneself a Nazi or a KKK member has lost its mark of shame in the United States.

The current administration in the U.S. has brought long-standing racism to the surface, illuminating the relevance of Baldwin's words for the present time. His talk called upon teachers to help youth consider their worlds and recognize injustices. As music educators, we seek a way for music and music education to 
challenge injustice and contribute to social change. In seeking an example of the ways in which music can profoundly shape public opinion, give voice to different perspectives, and respond to political events, we draw on A Tribe Called Quest's "We the People..." to explore the possibilities that music generates. The performance of "We the People..." at the 2016 Grammy Awards offers an example of the potential of music as a form of resistance, given explicit musical responses to events occurring post-election. We further consider ways to work alongside youth in schools to consider, process, and respond to these events. Baldwin urged teachers to engage youth in difficult conversations about the conditions surrounding them. We view music education as a means not only to have these conversations, but to offer creative musical responses to this political moment. Classrooms should not be viewed as apolitical; instead, teachers need to recognize the political forces influencing our educational spaces (Giroux 2011, 2019).

\section{Reflecting upon Baldwin's Talk to Teachers in 2018}

Looking to Baldwin's words from 1963, we consider the various systems and structures of oppression that need dismantling and our role as teachers in that process. Baldwin's words in 1963 emerged from a rich lineage of African American activism and scholarship. DuBois (2014), a scholar and one of the founders of the NAACP, famously wrote, "The problem of the twentieth century is the problem of the color-line" (3). A term originally coined by abolitionist Frederick Douglass (1881), addressing "the color line" has been a longstanding concern in the United States. Social reform initially aimed at abolition, over time came to target segregation and the violence and oppression directed at African Americans. At the time Baldwin gave "A Talk to Teachers," social reformers and scholars considered different ways to challenge segregation. These mechanisms included a separatist approach that opposed integration and promoted African American autonomy (see for example Marcus Garvey in Lawler and Davenport 2005 and Malcolm X 2003), an approach of compromise wherein southern African Americans guaranteed White political rule in exchange for fundamental rights such as education for African American people, as exemplified in Booker T. Washington's "Atlanta Compromise" (see Cunnigen, Dennis, and Glascoe 2006; Washington 2000), and ultimately anti-segregationist approaches such as DuBois' (1903) stance which advocated for full rights and civic participation.

Hess, Juliet, and Brent C. Talbot. 2019. Going for broke: A talk to music teachers. Action, Criticism, and Theory for Music Education 18 (1): 89-116. doi:10.22176/act18.1.89 
Education played a key role in executing all actions in response to segregation, violence, and oppression for these activists and scholars. They situated education as a means toward a different future for African Americans, whether through a focus on industrialization and agriculture to improve rural life (see for example Cunnigen, Dennis, and Glascoe 2006; Washington 2000) or a liberal arts approach that better prepared African Americans for political leadership (see DuBois 1903). Others, including DuBois (1903, 2014) and Carter Woodson (2009) considered the socialization processes that influenced the experiences of African Americans in the United States with a focus on navigating messages of inferiority, thus providing a strong precursor to Baldwin's call for a critical education. Woodson's (2009) important work, The Mis-education of the Negro, originally published in 1933, resisted the manner in which education had been used to create compliance and instead argued for an education that produces autonomous subjects. Baldwin's call for critical education builds upon previous demands for an education for African Americans that challenges education's role in the socialization of inferiority and compliance, and recognizes the role of education in perpetuating oppression in society.

Contemporary literature bolsters Baldwin's talk from the 1960s, illustrating the relevance of his words to the current climate. Baldwin centered the male subject in his talk. In doing so, he failed to acknowledge the ways in which the institutional and societal forces he identified affected women in ways both similar and distinct from men. In recognition of this shortcoming, our contextualization of his work takes a more intersectional perspective. We draw on Kimberlé Crenshaw's (1995) foundational work on intersectionality, alongside the work of Patricia Hill Collins' (2000) "matrix of domination," to consider the nature of the multiple identities held by all, and the manner in which they intersect and operate in different situations. Crenshaw (1995) demanded an accounting for gender in conversations about race, noting the ways in which both feminist discourses and anti-racist discourses at the time often failed to account for the experiences of Black women, as feminist discourses prioritized the experiences of White women, while anti-racist discourses addressed the concerns of Black men. Collins' (2000) "matrix of domination" provides a mechanism to understand intersections of identities and account for the kinds of omissions that Crenshaw (1995) identified. While Baldwin centered the male subject, however, some of his predecessors including W.E.B. DuBois and Frederick Douglass embraced what has become 
known as womanism (see Lemons 2009). Highly relevant to today, Baldwin's words still resonate strongly; by challenging the patriarchy inherent in his text, we aim to acknowledge the complexity of identities as they are affected by this political climate. In this section, we foreground Baldwin's words and subsequently discuss connections to the present context.

Black men [sic] were brought here as a source of cheap labor. They were indispensable to the economy. In order to justify the fact that men [sic] were treated as though they were animals, the white republic had to brainwash itself into believing that they were, indeed, animals and deserved to be treated like animals. Therefore it is almost impossible for any Negro child to discover anything about his actual history. The reason is that this "animal," once he suspects his own worth, once he starts believing that he is a man, has begun to attack the entire power structure. This is why America has spent such a long time keeping the Negro in his place [sic]. What I am trying to suggest to you is that it was not an accident, it was not an act of God, it was not done by wellmeaning people muddling into something which they didn't understand. It was a deliberate policy hammered into place in order to make money from Black flesh. And now, in 1963, because we have never faced this fact, we are in intolerable trouble. (Baldwin 1998, 681-2)

Now - in 2018-because we have never faced these facts, we are indeed in intolerable trouble. Racism and slavery are highly adaptable. Once one iteration or institution fails, another replaces it, perpetuating the legacies of slavery. The discourses people use to justify and prop up political systems that enforce status relations of any kind consistently evolve and change as people challenge them. The abolitionists' efforts to achieve greater racial equality prompted significant changes in the legal framework of American society (Alexander 2012). New rhetoric and a new social consensus, however, justify these new rules while producing many of the same results-what legal scholar Reva Siegel calls "preservation through transformation" (Siegel 1997, 1111 as cited in Alexander 2012, 21). This dynamic process maintains White supremacy, which allowed Jim Crow to replace slavery; Jim Crow was dismantled during the Civil Rights Movement only to become what Angela Davis (2000a) called the Prison Industrial Complex. ${ }^{3}$ As Michelle Alexander (2012) pointed out in The New Jim Crow:

Following the collapse of each system of control, there has been a period of confusion-transition-in which those who are most committed to racial hierarchy search for new means to achieve their goals within the rules of the game as currently defined. It is during this period of uncertainty that the backlash

Hess, Juliet, and Brent C. Talbot. 2019. Going for broke: A talk to music teachers. Action, Criticism, and Theory for Music Education 18 (1): 89-116. doi:10.22176/act18.1.89 
intensifies, and a new form of racialized social control begins to take hold.... The most ardent proponents of racial hierarchy have consistently succeeded in implementing new racial caste systems by triggering a collapse of resistance across the political spectrum. This feat has been achieved largely by appealing to the racism and vulnerability of lower-class whites, a group of people who are understandably eager to ensure that they never find themselves trapped at the bottom of the American hierarchy.... Moreover, as the systems of control have evolved, they have become perfected, arguably more resilient to challenge, and thus capable of enduring for generations to come. (21-2)

White supremacy operates through these mechanisms. As Smith (2006) argues, three pillars: slavery/capitalism, genocide/capitalism, and orientalism4/war, ensure the ongoing functioning of White supremacy as a dominant system. These pillars, in fact, co-constitute White supremacy, which functions as a result of ongoing colonialism, enslavement (and its contemporary manifestations as articulated above), and the Othering of immigrants to enable the capitalist system and wars on Others that include, for example, the war on terror (Buck-Morss 2003) and the war on drugs (Alexander 2012). Like Michelle Alexander's work, Smith's first pillar-slavery/capitalism-identifies how society commodifies Black bodies into labor through new forms of slavery, including the Prison Industrial Complex-a pipeline that begins in schools (Morris 2016).

Baldwin argues, "education occurs within a social framework and is designed to perpetuate the aims of society" (678). Education plays an important role in reproducing White supremacy. Through the concepts of habitus, field, and capital, 5 Pierre Bourdieu (1977a) demonstrated how the education system preserves existing social hierarchies. Institutions such as schools and universities, themselves products of established social hierarchies, recognize and reward certain values at the expense of others. As Bourdieu (1977a) wrote:

The educational system reproduces all the more perfectly the structure of the distribution of cultural capital among classes (and sections of a class) in that the culture which it transmits is closer to the dominant culture and that the mode of inculcation to which it has recourse is less removed from the mode of inculcation practiced by the family. (493)

Education is designed to reinforce the place of the dominant group at the top of the social hierarchy. While Bourdieu's perspective emerged from concerns about how French institutions reinscribed class structures, Baldwin spoke to how educational institutions bolstered racial caste systems. Mohandesi and Teitelman (2017) affirmed:

Hess, Juliet, and Brent C. Talbot. 2019. Going for broke: A talk to music teachers. Action, Criticism, and Theory for Music Education 18 (1): 89-116. doi:10.22176/act18.1.89 
By the turn of the century, the majority of states implemented a compulsory education system that served contradictory social purposes. If these public institutions subsidized care and promised new opportunities to the children of immigrants and working classes, they also served to inculcate, "Americanize," and propagate certain ideologies and cultural behaviors that were essential to forging a workforce and a nation. (50)

Social hierarchies affect various identities differently. The recent work of Tithi Bhattacharya and her colleagues (2017) extended social reproduction theory and explicitly linked it to their understanding of intersectionality, which accounts for both the classed hierarchies that Bourdieu identified and the racial caste system that Baldwin elucidated. Social reproduction theory further allows us to consider intersections of gender, ability, and sexual identities, acknowledging the complexities inherent in the "matrix of domination" that Collins (2000) identified. As in much of critical theory, social reproduction theory builds from Karl Marx's (1932) method for studying the commodity-a critical interrogative approach that holds up a mirror to the ways that we have organized our existence.

One of Bourdieu's major contributions to the social sciences revealed the ways in which agency is a marker of status. Bourdieu's (1990) writings on social reproduction contends that the social action of individuals is reflective of some combination of structure and agency, with structure most often operating in a deterministic way that constrains the freedom of agency. Baldwin, however, emphasized agency, as we elucidate later in this article. Notably, in most versions of reproduction theory, the agent is considered to be mostly unaware of how structural forces influence conduct.

Any Negro who is born in this country and undergoes the American educational system runs the risk of becoming schizophrenic. On the one hand he [sic] is born in the shadow of the stars and stripes, and he is assured it represents a nation which has never lost a war. He pledges allegiance to that flag which guarantees "liberty and justice for all." He is part of a country in which anyone can become president, and so forth. But on the other hand he is also assured by his country and his countrymen that he has never contributed anything to civilization-that his past is nothing more than a record of humiliations gladly endured. (Baldwin 1998, 679)

Baldwin's ideas here resonate with Du Bois' (2014) articulation of what he called, in 1903, "double consciousness" to describe the complexity of understanding oneself both as one feels while also recognizing the way that one is perceived by a racist society. Du Bois writes:

Hess, Juliet, and Brent C. Talbot. 2019. Going for broke: A talk to music teachers. Action, Criticism, and Theory for Music Education 18 (1): 89-116. doi:10.22176/act18.1.89 
It is a peculiar sensation, this double-consciousness, this sense of always looking at one's self through the eyes of others, of measuring one's soul by the tape of a world that looks on in amused contempt and pity. One ever feels his twoness,an American, a Negro; two souls, two thoughts, two unreconciled strivings; two warring ideals in one dark body, whose dogged strength alone keeps it from being torn asunder. (5)

Baldwin extended these ideas. His use of the term "schizophrenic" to describe the sensation of navigating this "twoness" likened this societal demand to a pathology, ${ }^{6}$ and further situates education as a mechanism for creating such pathology among Black students.

Legacies of enslavement and its modern-day incarnation in the Prison Industrial Complex (Davis 2000a), alongside the social reproductive function of school, shape the experiences of students in marginalized groups. Baldwin's identification of the risk of split-consciousness that occurs when an African American student enters the school system pointed to the disconnect between the version of the United States taught in school and the lived experiences of race and racism encountered daily by that same student. As Asante (1991) argued:

The little African-American child who sits in the classroom and is taught to accept as heroes and heroines individuals who defamed African people is being actively de-centered, dislocated, and made into a nonperson, one whose aim in life might one day be to shed that "badge of inferiority": his or her Blackness. (171)

The histories so often taught in school with erasures or tokenizing of enslavement and colonialism fail to recognize and account for legacies of oppression. Such misrecognition operates as a form of violence on the psyches of marginalized students. The choices for certain students then become either accepting one's erasure and dislocation, or as Baldwin argues, become "schizophrenic" as one navigates two disparate sets of narratives and experiences.

To ask questions of the universe, and then learn to live with those questions, is the way he [sic] achieves his own identity. But no society is really anxious to have that kind of person around. What societies really, ideally, want is a citizenry which will simply obey the rules of society. If a society succeeds in this, that society is about to perish. (Baldwin 1998, 678-9)

Rather than acknowledge the country's violent legacies, education-as a force for social reproduction-prioritizes compliance and docility. Reproducing the classes of society as they are through education demands that contributing members learn to capitulate to dominant discourse. Building upon the work of Carter Woodson 
(2009) from 1933, Baldwin points to the imperative of school to create what Foucault (1977) called "docile bodies" to perpetuate a society in which citizenry will "simply obey the rules," enacting the social reproductive function of school. Foucault's (1977) work on prisons explains the importance of docility in questions of power:

A "political anatomy," which was also a "mechanics of power," was being born; it defined how one may have a hold over others' bodies, not only so that they may do what one wishes, but so that they may operate as one wishes, with the techniques, the speed, and the efficiency that one determines. Thus discipline produces subjected and practised bodies, "docile" bodies. (138)

When education focuses on replicating the status quo rather than questioning it, school quashes any possibility of a different future. Current trends in globalized education focus on standardization (Sahlberg 2011) across curricular endeavors. Such trends fail to account for context and further encourage regurgitation and capitulation to the valuing of particular kinds of knowledges, fostering compliance. Baldwin cautions further, however, that with such focus on compliance, society will perish.

The purpose of education, finally, is to create in a person the ability to look at the world for himself [sic], to make his own decisions, to say to himself this is black or this is white, to decide for himself whether there is a God in heaven or not. (Baldwin 1998, 678).

If, as Baldwin feared, a compliant society will perish, education must move beyond a model that rewards docility to an approach that fosters critical thinking. Indeed, Baldwin identified such ability to critically examine the world as the very purpose of education. hooks (2009) argues that "children are organically predisposed to be critical thinkers," becoming, at times, "relentless interrogators" (7). She cautions, however:

Children's passion for thinking often ends when they encounter a world that seeks to educate them for conformity and obedience only. Most children are taught early on that thinking is dangerous. Sadly, these children stop enjoying the process of thinking and start fearing the thinking mind. Whether in homes with parents who teach via a model of discipline and punish that it is better to choose obedience over self-awareness and self-determination, or in schools where independent thinking is not acceptable behavior, most children in our nation learn to suppress the memory of thinking as a passionate, pleasurable activity. (8)

Hess, Juliet, and Brent C. Talbot. 2019. Going for broke: A talk to music teachers. Action, Criticism, and Theory for Music Education 18 (1): 89-116. doi:10.22176/act18.1.89 
Like Baldwin, hooks renounced education for compliance and advocated for "engaged pedagogy." Critical thinking, she argued, involves "radical openness" (10) - a pedagogy that allows for multiple perspectives and the possibility of encountering something unknown. Deciding for ourselves how we perceive the world, as Baldwin urged, moves us away from a compliance model of education toward an engaged pedagogy, through which we may encounter issues incongruous with current understandings. Attending to issues that are detrimental to our own safety, security, and welfare or that of others demands efforts toward transformation-a Freirian ideal of education. Critical thinking necessitates transformation; to "name the world" (Freire 2000/1970) requires explicit work to change it.

The obligation of anyone who thinks of himself [sic] as responsible is to examine society and try to change it and to fight it-at no matter what risk. This is the only hope society has. This is the only way societies change. (Baldwin 1998, 679)

Baldwin thus identified societal transformation as a key goal of critical thinking. He imbued responsibility in individuals, challenging us to change society upon identifying structural issues. The focus on individuals points directly to the role we all play in changing systems. In anti-oppressive education (e.g. Kumashiro 2000) including anti-racism, for example, we often speak of the importance of focusing our attention on structural and systemic racism, as opposed to individual racist acts (Dei 2003).7 Baldwin directed his call to action to individuals, recognizing that individuals will ultimately change the system. He elaborated:

I began by saying that one of the paradoxes of education was that precisely at the point when you begin to develop a conscience, you must find yourself at war with your society. It is your responsibility to change society if you think of yourself as an educated person. (Baldwin 1998, 685)

A critical education-as distinct from the socialization process of educationrequires action toward change. Once one develops critical consciousness (Freire 2000/1970), change-making becomes intrinsic to education. Baldwin focused on racial stratification when encouraging students to come to consciousness, urging them toward action once they develop awareness of the system. Action depends upon individuals in oppressed groups who refuse to make peace with what Baldwin 
called the criminal conspiracy facing African Americans. Changing society, however, requires envisioning different possibilities:

I would try to make each child know that these things [those streets, those houses, those dangers, those agonies by which they are surrounded] are the result of a criminal conspiracy to destroy him [sic]. I would teach him that if he intends to get to be a man, he must at once decide that he is stronger than this conspiracy and that he must never make his peace with it. And that one of his weapons for refusing to make his peace with it and for destroying it depends on what he decides he is worth. (Baldwin 1998, 685)

Baldwin again underscored the imperative for action and transformation, but his words here further point to questions of self-worth. When individuals in oppressed groups come to believe that they are valuable, refusing to accept any societal discourse and action that indicates otherwise becomes crucial to eschewing the split-consciousness Baldwin identified that results from encountering narratives that vastly contradict one's lived experiences. Baldwin's notion of becoming split speaks directly to the narrative of US liberty encountered in schools that dramatically differs from the racism encountered by African Americans in daily life. The type of contradictions identified here, however, point to the disconnect between recognizing oneself as inherently valuable while continually receiving societal messages to the contrary. Groups targeted by societal discourses and practices of racism and colonialism often internalize strong communications of "less than" inherent in such systems. Internalized racism, as described for example by Fanon (1963), Adjei (2010), and hooks (in Valdivia 2002), causes "Black people [to] learn to think of themselves as White supremacist culture renders them" (Valdivia 2002, 439)-as "less than."

Once one recognizes one's value, it becomes essential to resist being deemed disposable (Giroux 2006) or enslaveable (Smith 2006). Hess (2013) identified the importance of instilling a sense of value within students alongside an intersectional understanding of their positionalities as a crucial aspect of anti-oppression education. When an essential element of education involves helping students understand their inherent value, we, as educators, encourage students to refuse to accept any discourses or actions that deny their value.

Where there is no vision the people perish. I don't think anyone can doubt that in this country today we are menaced-intolerably menaced-by a lack of vision. (Baldwin 1998, 684) 
While Baldwin stressed learning to think critically and acting for transformation, toward the end of $A$ Talk to Teachers, he pointed to the necessity of vision. Enacting transformation requires social imagination (Greene 1995; 2001). To speak of vision in education, however, invokes particular assumptions about imagination that often obscure the situated historical socio-cultural aspects that structure and condition vision. Greene (1995) called upon us to "look at things as if they could be otherwise" (16) and to intricately connect the arts to fostering both imagination and critical consciousness. If education, as Baldwin argued, demands transformation, we must have vision for a future beyond the oppressive systems that different groups encounter daily. For social change to occur, as educators we must question the system's legitimacy. Even when we challenge these structures, bureaucratic organization helps to ensure that resistance is kept in check (Mantie and Talbot 2015).

In a political moment in which oppressive systems and political forces constrain, erase, and violate particular bodies, we look to A Tribe Called Quest as an example of how musicians have taken up the call to oppose oppression. We argue that they allow us to consider possible mechanisms through which music education might play a role in resistance. "To any citizen of this country who figures himself [sic] as responsible-and particularly those of you who deal with the minds and hearts of young people-must be prepared to 'go for broke'” (Baldwin 1998, 678).

\section{Going for Broke: The Imperative of Art in Troubled Times}

The critically acclaimed 2016 hit, "We the People...." is a song by American hiphop group, A Tribe Called Quest, from the album We got it from Here ... Thank You 4 Your service. Known for their activism and for promoting Afrocentrism ${ }^{8}$ through their music, ${ }^{9}$ A Tribe Called Quest wrote "We the People..." after the group reunited on November 13, 2015-the same night as the Paris attacks ${ }^{10}$ (Ray 2018). The chorus of the politically-charged song parodies the rhetoric ${ }^{11}$ of hate surrounding Trump's presidential campaign, stating that all of "our bad folks" (Black, poor, Mexicans, Muslims, and gays ${ }^{12}$ ) "must go!"

\section{Analysis of the Grammy Performance}

To consider the role of art, we look to Audre Lorde, who wrote: 
For women, then, poetry is not a luxury. It is a vital necessity of our existence. It forms the quality of the light within which we predicate our hopes and dreams toward survival and change, first made into language, then into idea, then into more tangible action. Poetry is the way we help give name to the nameless so it can be thought. (Lorde 1984/2007, 38)

Audre Lorde-poet, activist, and scholar-routinely demanded justice for those groups relegated to the margins. Her own positionality as a Black lesbian woman shaped her call for deep acknowledgment of the complexities of intersecting identities and the manner in which marginalization and privilege oppress and/or enable at the intersections (see also Collins 2000). Lorde spoke compellingly to the necessity of art in troubled times. Music, too, is not a luxury, and Baldwin called us to "go for broke." In the capitalist space of the Grammys, which perpetuates Whiteness as a dominant ideology, A Tribe Called Quest went for broke. Given this platform, they powerfully challenged the Trump regime in the United States on live national television. Baldwin situated critical thinking, transformation, and vision squarely among the purposes of education when he said:

\section{The purpose of education, finally, is to create in a person the ability to look at the world for himself, to make his own decisions,... to ask questions of the universe, and then learn to live with those questions, is the way he achieves his own identity. (Baldwin 1998, 678)}

We argue that music can serve as provocation-provoking society to question-to direct our gaze toward the violence in discourse and action. We examined three aspects of "We the People..." to consider how A Tribe Called Quest used their music to provoke individuals to resist oppression and "go for broke."

\section{Opening and closing ${ }^{13}$}

Busta Rhymes opened the Grammy performance of "We the People..." by beginning a dialogue with Consequence, stating: "I'm not feeling the political climate right now." He then addressed "President Agent Orange," thanking him "for perpetuating all of the evil that [he's] been perpetuating throughout the United States" and saluting him before "congratulating" him on his "unsuccessful Muslim ban"14-a personal matter for A Tribe Called Quest's Muslim members Q-Tip and Ali Shaheed Muhammad. The dialogue seamlessly transitioned into music after Busta shouted, "When we come together, We the People!" as A Tribe Called Quest, flanked by a woman in a hijab and an entourage of so-called Others broke through 
Trump's "great wall." A rare moment in mainstream media, the final word of the performance: "Resist!"-delivered with Black-power salutes in the air-denounced the prevalent discourse of fear and intolerance in the United States.

\section{Driving it home: Making real the abstraction}

While A Tribe Called Quest delivered their searing critique, a line of people visibly representing those who "must go" under Trump's regime made their way through the audience, arriving onstage on the hook, which embodies words presumably from a Trump-regime hatemonger: "all of our bad folks, you must go!" Trump's rhetoric about building the wall and the Muslim Ban perhaps communicated this violence abstractly. A Tribe Called Quest actualized what these policies would mean, visually showing us "who must go" and refusing to let White audience members look away. Far from abstract, these discourses and potential policies enact material violence. The unaffected segment of the population, however, could easily fail to recognize the reality of such policies. This "parade" of affected bodies calls out complicity. To remain silent implicates us in the violence. Coupling this powerful visual message with their devastating lyrics, A Tribe Called Quest offers us a choice-resistance or complicity-imbuing us with the individual responsibility Baldwin charged.

\section{Speaking truth to power: Calling it all out}

In three minutes, A Tribe Called Quest highlighted urgent issues facing minoritized groups under Trump's regime. They delivered a searing critique of U.S. White supremacist attitudes toward immigration and Trump's proposed "wall" at the U.S./Mexico border, and obliquely criticized Hillary Clinton's pandering to minority groups. They challenged displacement enacted by gentrification and identified the systemic violence certain bodies experience, while ironically highlighting commonalities between groups. They condemned the gender pay gap, critiqued colonialism and Western civilization, and criticized the news media, closing with a fierce gesture of resistance aimed at "Agent Orange"-Donald Trump. Baldwin imbued citizens with responsibility for changing society. The sheer number of issues A Tribe Called Quest raised lays bare injustices in the U.S. and urges us to resist. Speaking truth to power by identifying oppression becomes a mechanism through which musicians can "go for broke." 
A Tribe Called Quest's Grammy performance is thus distinctly educative on Baldwin's terms-his demand for education to involve critical thinking, transformation, and vision. Serving as provocation, "We the People..." makes palpable the consequences of Trump's then-proposed actions. ${ }^{15}$ The performance and song itself urge the public to critically actualize the events that could well take place and "look at things as if they could be otherwise" (Greene 1995, 16). They demand that the U.S. population resist the Trump regime and transform the present path through overt refusal of proposed and actualized policies.

\section{Going for Broke: Teaching Music in Troubled Times}

Baldwin insisted on a more honest reckoning with history. Focusing on our collective histories prompts purposeful unlearning of discourses projected onto Black bodies. Unlearning is especially necessary for White children who too often purvey these myths. Learning our histories, as Baldwin notes, can provoke cognitive dissonance and frustration. Speaking about hypothetical students, Baldwin offered:

\section{I would try to teach them-I would try to make them know, that those streets, those houses, those dangers, those agonies by which they are surrounded, are criminal" (Baldwin 1998, 685).}

English educator Clint Smith writes, "Baldwin, with literary sleight of hand, adopts the terminology used to pathologize Black people and applies it to the system in which they operate." In a parallel approach, Afrocentrist artists like A Tribe Called Quest use irony to pathologize race, ethnicity, class, religion, and sexual identities, repositioning the narrative. This repositioning, according to Asante (2009), is essential to the Afrocentric paradigm:

One of the key assumptions of the Afrocentrist is that all relationships are based on centers and margins and the distances from either the center or the margin. When black people view themselves as centered and central in their own history, then they see themselves as agents, actors, and participants rather than as marginals on the periphery of political or economic experience. (2)

In response to Baldwin's "A Talk to Teachers," Smith (2017) wrote:

After reading 'A Talk to Teachers,' I altered my approach ... using literature to help my students examine their world. I realized that rigorous lessons were not

Hess, Juliet, and Brent C. Talbot. 2019. Going for broke: A talk to music teachers. Action, Criticism, and Theory for Music Education 18 (1): 89-116. doi:10.22176/act18.1.89 
mutually exclusive from culturally and politically relevant ones. Shakespeare's "Julius Caesar" did not have to be sacrificed in order to make room for a discussion on community violence. Ralph Ellison's "Invisible Man" did not have to be abandoned in order to tackle immigration. "A Talk to Teachers" showed me that a teacher's work should reject the false pretense of being apolitical, and, instead, confront the problems that shape our students' lives.

Similarly, in music education, we need not disavow Western classical music to engage with multiple musics. ${ }^{16}$ Rather, we can create opportunities to talk about the significance accorded to particular types of music and the manner in which school curricula often hierarchize musics. Without pretense of being apolitical, we can engage with students about musics they encounter. Baldwin noted, "where there is no vision the people perish." In these times, music education may help us identify ways to resist oppressive political regimes and envision justice.

Music presents an opportunity to engage the world critically. Hip-hop, as A Tribe Called Quest demonstrates, can critically challenge current events. Social commentary, however, is not unique to hip-hop. While hip-hop emerged in the late 1970s to speak to challenges and injustices faced by individuals in the Bronx (Chang 2005), songs across multiple genres engage the world, speaking to experiences that resonate with their audiences. "We the People..." critically challenges conditions in the U.S. Youth in schools can similarly use music to critique their world and address challenges they face. As Baldwin imagined about his students:

I would try to make him [sic] know that just as American history is longer, larger, more various, more beautiful and more terrible than anything anyone has ever said about it, so is the world larger, more daring, more beautiful and more terrible, but principally larger-and that it belongs to him ... I would teach him that he doesn't have to be bound by the expediencies of any given administration, any given policy, any given morality, that he has the right and the necessity to examine everything. (Baldwin 1998, 685-6)

Music presents an opportunity to examine the world-an opportunity that artists have taken up continually across multiple time periods. When we, as music educators, engage with young musicians, we can encourage them to speak to issues of great import to their lives. We can also consider how music education might prompt individuals to take responsibility for our role in structural oppressions. A Tribe Called Quest powerfully shows us our implication in dominant systems and urges us to resist. Through engaging with musics that point to different struggles, 
music education provides similar opportunities to explore complicity in oppression. A Tribe Called Quest offers listeners two possibilities: (1) we can remain uncomfortable with the way they call out events in the US or (2) we can move to action-the transformation Baldwin demanded. When teachers and students use music to address social issues, they can position their music in a way that moves toward action.

Baldwin points to vision as imperative in shifting oppression. Music can provide searing critiques of current events. The imagining or vision may perhaps rest in what songs like "We the People..." expose-that the current state of the U.S. is untenable and on a trajectory towards fascism and totalitarianism; we need to divert our current path towards a more just and equitable society. Music education, however, may offer further potential for imagining. Critique remains essential to recognizing systemic and structural oppression. Baldwin calls on us to make change. In a recent songwriting project with students in Detroit, youth wrote hiphop songs about "their Detroit" and fiercely rewrote the deficit narratives that framed their lives. In doing so, they created a different vision of their own experiences and refused societal discourse about them (Hess 2018).

Music education offers possibilities to create a narrative toward a different possible future. Youth bring a wealth of experiences to the music classroom and music, as exemplified by A Tribe Called Quest, offers a vehicle for them to express their experiences in ways that resonate with their communities and shape possible actions and response. Centering the critical education proposed by Baldwin, following Woodson (2009), music educators can work alongside youth to facilitate the recognition of injustice both in schools and in society, and give them a powerful means to respond, to resist. Such musical resistance is bold, and perhaps dangerous. ${ }^{17}$ Oppressive regimes, however, demand response, and music education is well positioned to provide a vehicle for expression. So the question becomes: Are we as music educators prepared to "go for broke?"

\section{About the Authors}

Juliet Hess is an assistant professor of music education at Michigan State University, where she teaches secondary general methods in music education, principles in music education, and philosophy and sociology of music education. Juliet received her Ph. D. in Sociology of Education from the Ontario Institute for Studies in Education at the University of Toronto. She previously taught elementary and middle school vocal, instrumental, and "world" music at a public school in the 
Greater Toronto Area. Her research interests include anti-oppression education, activism in music and music education, music education for social justice, and the question of ethics in world music study.

Brent C. Talbot is an associate professor and the coordinator of music education at the Sunderman Conservatory of Music of Gettysburg College. He is the artistic director of the Gettysburg Children's Choir and the founding director of Gamelan Gita Semara. Brent's research examines power, discourse, and issues of justice in varied settings for music learning around the globe. He is the editor of Marginalized Voices in Music Education (Routledge) and the author of Gending Rare: Children's Songs and Games from Bali (GIA). Brent serves as the convener of the steering committee for the MayDay Group and is on the editorial boards of Action, Criticism, and Theory for Music Education and the Bulletin of the Council for Research in Music Education. For more, visit www.brentctalbot.com.

\section{References}

Adjei, Paul. 2010. Resistance to amputation: Discomforting truth about colonial education in Ghana. In Fanon and education: Thinking through pedagogical possibilities, edited by George J. Sefa Dei and Marlon Simmons, 79-104. New York: Peter Lang.

Alexander, Michelle. 2012. The new Jim Crow: Mass incarceration in the age of colorblindness. New York, NY: The New Press.

Asante, Molefi Kete. 1991. The Afrocentric idea in education. Journal of Negro Education 60 (2):170-80.

Asante, Molefi Kete. 2009. Afrocentricity. Retrieved from http://www.asante.net/ articles/1/afrocentricity/ on December 20, 2018.

A Tribe Called Quest. 2016. We the People... We Got it From Here ... Thank You 4 Your Service. Epic Records Group. Bo1LTHY42W.

Bakalar, Nicholas. 2017. Nearly 20 million have gained health insurance since 2010. The New York Times (May 22). Retrieved from https://www.nytimes. com/2017/05/22/health/obamacare-health-insurance-numbers-nchs.html on December 18, 2018.

Baldwin, James. 1998. A talk to teachers. In James Baldwin: Collected essays, edited by Toni Morrison, 678-86. New York: Literary Classics of the United States, Inc.

Bhattacharya, Tithi, ed. 2017. Social reproduction theory: Remapping class, recentering oppression. London, UK: Pluto Press.

Hess, Juliet, and Brent C. Talbot. 2019. Going for broke: A talk to music teachers. Action, Criticism, and Theory for Music Education 18 (1): 89-116. doi:10.22176/act18.1.89 
Bourdieu, Pierre. 1977a. Outline of a theory of practice. Cambridge, UK: Cambridge University Press.

Bourdieu, Pierre. 1977b. Cultural reproduction and social reproduction. In Power and ideology in education, edited by Jerome Karabel and A. H. Halsey, 487510. Oxford, UK: Oxford University Press.

Bourdieu, Pierre. 1990. Reproduction of education, society, and culture. Thousand Oaks: Sage Publications.

Bourdieu, Pierre. 1993. The field of cultural production: Essays on art and literature, edited by Randal Johnson. New York: Columbia University Press.

Bradley, Deborah. 2006. Education, multiculturalism, and anti-racism: Can we talk? Action, Criticism, and Theory for Music Education 5 (2): 1-30.

Bradley, Deborah. 2007. The sounds of silence: Talking race in music education. Action, Criticism, and Theory for Music Education 6 (4): 132-62.

Buck-Morss, Susan. 2003. Thinking past terror: Islamism and critical theory on the left. New York: Verso.

Canfield, David. February 13, 2017. A Tribe Called Quest showed the Grammys how political statements are done. Slate. Retrieved from http://www.slate. $\mathrm{com} / \mathrm{blogs} / \mathrm{browbeat} / 2017 / 02 / 13 /$ a_tribe_called_quest_showed_the_gram mys_how_political_statements_are_done.html on May 24, 2018.

Chang, Jeff. 2005. Can't stop won't stop: A history of the hip-hop generation. New York, NY: St. Martin's Press.

Charlottesville: Race and Terror. 2017. VICE News Tonight on HBO. New York: Vice Productions, LLC. Retrieved from https://www.youtube.com/watch? v=RIrcB1sAN8I on September 16, 2018.

Crenshaw, Kimberlé. 1995. Mapping the margins: Intersectionality, identity politics, and violence against women of color. In Critical race theory: The key writings that formed the movement, edited by Kimberle Crenshaw, Neil Gotanda, Gary Peller and Kendall Thomas, 357-83. New York, NY: The New Press.

Cohen, Joshua. July 6, 2018. "Troublesome news: Numbers of uninsured on the rise." Forbes. Retrieved from https://www.forbes.com/sites/joshuacohen /2018/07/o6/troublesome-news-numbers-of-uninsured-on-therise/\#6a39428d4309 on December 18, 2018.

Hess, Juliet, and Brent C. Talbot. 2019. Going for broke: A talk to music teachers. Action, Criticism, and Theory for Music Education 18 (1): 89-116. doi:10.22176/act18.1.89 
Cohen, Robin A., Emily P. Zammitti, and Michael E. Martinez. May, 2017. Health insurance coverage: Early release of estimates from the National Health Interview Survey, 2016. National Center for Health Statistics. Retrieved from https://www.cdc.gov/nchs/data/nhis/earlyrelease/insur201705.pdf on December 18, 2018.

Collins, Patricia Hill. 2000. Black feminist thought: Knowledge, consciousness, and the politics of empowerment. 2nd ed. New York, NY: Routledge.

Cunnigen, Donald, Rutledge M. Dennis, and Myrtle Gonza Glascoe, eds. 2006. The racial politics of Booker T. Washington. Edited by Rutledge M. Dennis, Research in race and ethnic relations. New York, NY: Elsevier.

Davis, Angela. 2000a. The prison industrial complex. Oakland, CA: AK Press.

Davis, Angela. 200ob. Masked racism: Reflections on the prison industrial complex. Indigenous Law Bulletin 4 (27): 4-7.

Dei, George J. Sefa. 2003. Anti-racism education: Theory and practice. Halifax, NS: Fernwood.

Douglass, Frederick. 1881. The color line. The North American Review 132 (295): $567-77$.

Du Bois, William Edward Burghardt. 2014. The souls of Black folk. Middletown, DE: Millennium Publications.

DuBois, William Edward Burghardt. 1903. The talented tenth. Accessed from TeachingAmericanHistory.org on December 20, 2018. http://teaching americanhistory.org/library/document/the-talented-tenth/.

Elliott, David, and Marissa Silverman. 2014. Music matters: A philosophy of music education. New York: Oxford University Press.

Fanon, Frantz. 1963. The wretched of the earth. Translated by Richard Philcox. New York, NY: Grove Press.

Foucault, Michel. 1977. Discipline and punish: The birth of the prison. Translated by Alan Sheridan. New York, NY: Vintage Books.

Freire, Paulo. 2000/1970. Pedagogy of the oppressed: 3oth anniversary edition. Translated by Myra Bergman Ramos. New York, NY: Continuum.

Hess, Juliet, and Brent C. Talbot. 2019. Going for broke: A talk to music teachers. Action, Criticism, and Theory for Music Education 18 (1): 89-116. doi:10.22176/act18.1.89 
Giroux, Henry A. 2006. Stormy weather: Katrina and the politics of disposability. Boulder, CO: Paradigm Publishers.

Giroux, Henry A. 2011. On critical pedagogy. New York: Continuum.

Giroux, Henry A. 2019. Authoritarianism and the challenge of higher education in the age of Trump. Action, Criticism, and Theory for Music Education 18 (1).

Goble, Scott. Ed. 2010. What's so important about music education? New York: Routledge.

Greene, Maxine. 1995. Releasing the imagination: Essay on education, the arts, and social change. San Francisco, CA: Jossey-Bass.

Greene, Maxine. 2001. Variations on a blue guitar: The Lincoln Center Institute lectures on aesthetic education. New York, NY: Teachers College Press.

Hess, Juliet. 2013. Radical musicking: Challenging dominant paradigms in elementary music education. PhD diss., University of Toronto.

Hess, Juliet. 2015. Upping the "anti-": The value of an anti-racist theoretical framework in music education. Action, Criticism, and Theory for Music Education 14 (1): 66-92.

Hess, Juliet. 2018. Detroit youth speak back: Rewriting deficit perspectives through songwriting. Bulletin of the Council for Research in Music Education 216: 7-30.

hooks, bell. 2009. Teaching critical thinking: Practical wisdom. New York, NY: Routledge.

Kumashiro, Kevin. K. 2000. Toward a theory of anti-oppressive education. Review of Educational Research 70 (1): 25-53.

Lawler, Mary, and John Davenport. 2005. Marcus Garvey: Black nationalist leader. Philadelphia, PA: Chelsea House Publishers.

Lemons, Gary L. 2009. Womanist forefathers: Frederick Douglass and W.E.B. DuBois. Albany, NY: State University of New York Press.

Lind, Dara, Liz Schedltens, and Silvia Philbrick. 2017. Daca, explained. Vox. Retrieved from https://www.youtube.com/watch?v=UzYDqQDNFzc on September 16, 2018. 
Liptak, Adam, and Michael Shear. June 26, 2018. Trump's travel ban is upheld by Supreme Court. The New York Times. Retrieved from https://www. nytimes.com/2018/o6/26/us/politics/supreme-court-trump-travel-ban.html on December 20, 2018.

Lorde, Audre. 1984/2007. Sister outsider: Essays and speeches. Berkeley, CA: The Crossing Press.

Malcolm X. 2003. Racial separation. In Civil Rights: Great speeches in history, edited by Jill Karson, 50-57. Farmington Hills, MI: Greenhaven Press.

Mantie, Roger, and Brent C. Talbot. 2015. How can we change our habits if we don't talk about them? Action, Criticism, and Theory for Music Education 14 (1): 128-53. act.maydaygroup.org/articles/MantieTalbot14_1.pdf

Marcolini, Barbara and Ben Decker. 2017. How the violence unfolded in Charlottesville. New York Times. Retrieved from https://www.nytimes.com /video/us/100000005363670/charlottesville-virginia-white-nationalistprotests.html on September 16, 2018.

Marx, Karl. 1932. Capital: The Communist manifesto. New York, NY: Random House.

Mohandesi, Salar, and Emma Teitelman. 2017. Without reserves. In Social reproduction theory: Remapping class, recentering oppression, edited by Tithi Bhattacharya, 37-67. London, UK: Pluto Press.

Morris, Monique. 2016. Pushout: The criminalization of Black girls in schools. New York: The New Press.

Nixon, Ron, and Linda Qiu. 2018. Trump's evolving words on the wall. New York Times. Retrieved from https://www.nytimes.com/2018/o1/18/us/politics/ trump-border-wall-immigration.html on September 16, 2018.

New York Times. 2015. Three hours of terror inParis: Moment by moment. Retrieved from https://www.nytimes.com/interactive/2015/11/13/world/europe/ paris-shooting-attacks.html on September 16, 2018.

Panduranga, Harsha, Faiza Patel, and Michael W. Price. 2017. Extreme vetting and the Muslim Ban. New York, NY: Brennan Center for Justice at the New York University School of Law. Retrieved from https://www.courthouse news.com/wp-content/uploads/2017/10/brennan-vetting-report.pdf on September 16, 2018.

Hess, Juliet, and Brent C. Talbot. 2019. Going for broke: A talk to music teachers. Action, Criticism, and Theory for Music Education 18 (1): 89-116. doi:10.22176/act18.1.89 
Regelski, Thomas. 2016. A brief introduction to a philosophy of music and music education as social praxis. New York: Routledge.

Ray, Michael. 2018. "Paris attacks of 2015." Encyclopedia Britannica. Retrieved from https://www.britannica.com/event/Paris-attacks-of-2015 on September 16, 2018.

Rovner, Julie. 2018, April 5. Timeline: Despite GOP's failure To repeal Obamacare, the ACA has changed. The Washington Post. Retrieved from https://www. washingtonpost.com/national/health-science/timeline-despite-gops-failureto-repeal-obamacare-the-aca-has-changed/ 2018/o4/o5/dba36240-38b1-11e8-af3c-2123715f78df_story.html?utm_ term $=$. b1799294fc46 on September 16, 2018.

Said, Edward W. 1978. Orientalism. New York: Vintage Books.

Sahlberg, Pasi. 2011. Finnish lessons: What can the world learn from educational change in Finland? New York, NY: Teachers College Press.

Siegel, Reva. 1997. Why equal protection no longer protects: The evolving forms of status-enforcing action. Stanford Law Review 49: 1111-48.

Smith, Andrea. 2006. Heteropatriarchy and the three pillars of white supremacy: Rethinking women of color organizing. In Color of violence: The Incite! Anthology edited by INCITE! Women of Color Against Violence, 66-73. Cambridge, MA: South End Press.

Smith, Clint. 2017. James Baldwin's lesson for teachers in a time of turmoil. The New Yorker (September 23). New York, NY: Conde Naste. Retrieved from https://www.newyorker.com/books/page-turner/james-baldwins-lessonfor-teachers-in-a-time-of-turmoil on May 24, 2018.

Talbot, Brent C. 2018. Introduction. In Marginalized voices in music education, edited by Brent C. Talbot, 1-12. New York: Routledge.

Toure. March 24, 2016. The legacy of a Tribe Called Quest. The New York Times. Retrieved from https://www.nytimes.com/2016/03/25/opinion/the-legacyof-a-tribe-called-quest.html on December 20, 2018.

Valdivia, Angharad. 2002. bell hooks: Ethics from the margins. Qualitative Inquiry 8 (4): 429-47.

Veterans of the Civil Rights Movement - History \& Timeline. 1963 January to June. Retrieved from www.crmvets.org. http://www.crmvet.org/tim/tim his63.htm on January 17, 2018.

Hess, Juliet, and Brent C. Talbot. 2019. Going for broke: A talk to music teachers. Action, Criticism, and Theory for Music Education 18 (1): 89-116. doi:10.22176/act18.1.89 
Washington, Booker T. 2000. Up from slavery: An autobiography. In. Virginia: Rector and Visitors of the University of Virginia. http://etext.lib. virginia.edu/modeng/modengW.browse.html.

Willis, Carl. 2017. Parents outraged after teacher gives profanity-laced homework assignment. WSB-TV2 Atlanta, September 20. Accessed November 26, 2018. https://www.wsbtv.com/news/local/parents-outraged-after-teacher-givesprofanity-laced-homework-assignment/611724103.

Wilson, Mike. 2017, August 15. Trump should accept rulings against move to dump DACA, return to Congress to broker a deal. Dallas News. Retrieved from https://www.dallasnews.com/opinion/editorials/2018/o8/15/trump-acceptrulings-move-dump-daca-return-congress-broker-deal on September 16, 2018.

Webb, Jen, Tony Schirato, and Geoff Danaher. 2002. Understanding Bourdieu. London: Sage Publications.

Woodson, Carter Godwin. 2009. The mis-education of the negro. U.S.: Clear Worlds.

\section{Notes}

1 This paper draws upon a significant portion of Baldwin's text from his work (1963), "A Talk to Teachers." Borrowing from narrative research, we have chosen to represent Baldwin's words throughout the paper in a different text and format for easier identification and reading.

2 On March 23, 2010, then-U.S. president Barack Obama signed the Patient Protection and Affordable Care Act into law. The number of Americans without health insurance dropped from 48 million uninsured Americans in 2010 to 28.6 million in 2016 (Bakalar 2017). According to data reported by Cohen et al. (2017) at the National Center for Health Statistics, some 12.4 percent of adults aged 18 to 24 were uninsured, 69.2 percent were covered by private plans and 20 percent had public coverage. However, in May of 2018, the numbers of people in the U.S. without health insurance have risen to $15.5 \%$, up from $12.7 \%$ in 2016. This translates to an increase of four million uninsured people nationwide. According to Cohen (2018) at Forbes, it seems President Trump's "attempts to unravel the Affordable Care Act appear to be working." 
3 As Angela Davis (200ob) points out in Masked Racism: Reflections on the Prison Industrial Complex: "Almost two million people are currently locked up in the immense network of U.S. prisons and jails. More than 70 percent of the imprisoned population are people of color. It is rarely acknowledged that the fastest growing group of prisoners are black women and that Native American prisoners are the largest group per capita. Approximately five million people-including those on probation and parole-are directly under the surveillance of the criminal justice system.” https://www.historyisaweapon.com/defcon1/davisprison.html

4 Orientalism, drawing on Said's (1978) volume, describes the manner in which the West typically characterizes and represents the East in ways that exacerbate Western superiority and reproduce power hierarchies diminishing the East. In the context of Smith's (2006) pillar “orientalism/war," the understanding of the East as inferior justifies measures of war.

5 Academics in the field of Education have embraced the theoretical vocabulary of French sociologist Pierre Bourdieu for its rich explanations of how social hierarchies are created and sustained. According to Bourdieu (1993), a given practice is the result of, or comprises, habitus, capital, and field. Building upon the theories of Heidegger, Wittgenstein, Weber, Marx, Durkheim, among others, Pierre Bourdieu emphasized the importance of the body and practices within social life. Bourdieu's "Theory of Practice" (1977b) views each individual as occupying a position in a multidimensional social space, where the individual holds social, cultural, economic, and symbolic capital that can or cannot be exchanged within specific settings. Bourdieu shows how individuals are not only defined by social class membership within their social practices, but how each individual is also defined by the kind of capital each individual can articulate and/or access through social relations within the structure of participation.

A field, according to Bourdieu (1993), is a setting in which agents and their social positions are located. The position of each particular agent in the field is a result of interaction between the specific rules of the field, agent's habitus and agent's capital (social, economic and cultural). Fields interact with each other, and are hierarchical: Most are subordinate to the larger field of power and class relations. Instead of confining his analysis of social relations and change to voluntaristic agency or strictly in terms of class as a structural relation, Bourdieu uses the agency-structure bridging concept of field: any historical, nonhomogeneous social-spatial arena in which people maneuver and struggle in pursuit of desirable resources. Much of Bourdieu's work observes the semiindependent role of educational and cultural resources in the expression of agency.

Hess, Juliet, and Brent C. Talbot. 2019. Going for broke: A talk to music teachers. Action, Criticism, and Theory for Music Education 18 (1): 89-116. doi:10.22176/act18.1.89 
Bourdieu's conception of the mechanism that educational systems employ to reproduce existing social relations in students is relevant for this paper. Webb et al.'s description of habitus is helpful in connecting to Baldwin's description of education: "The habitus is thus the means through which the values and relations of the school are inculcated and reproduced within the child. The child will take to school the habitus they have acquired in their early years within the home, and that habitus will be acted on by their experiences at school. So, for Bourdieu, home and family life also play a significant role in social reproduction, as the degree to which the child's family habitus fits in with the school habitus has consequences for the success of the child in acquiring the values, dispositions and cultural capital that characterise the school" (Webb et al. 2002, 116).

${ }^{6}$ The use of the term schizophrenic to describe a phenomenon that is distinct from schizophrenia has ableist overtones. Baldwin's use of the term and our subsequent use of the word pathology, however, point to the extremity of the effect of this twoness on those individuals and groups who experience it.

7 For examples of how racism and anti-racism operate in music education, see Bradley (2006, 2007) and Hess (2015).

8 According to Dr. Molefi Kete Asante-a leading scholar of Afrocentrism, "the Afrocentric paradigm is a revolutionary shift in thinking proposed as a constructural adjustment to black disorientation, de-centeredness, and lack of agency. The Afrocentrist asks the question, 'What natural responses would occur in the relationships, attitudes toward the environment, kinship patterns, preferences for colors, type of religion, and historical referent points for African people if there had not been any intervention of colonialism or enslavement?' Afrocentricity answers this question by asserting the central role of the African subject within the context of African history, thereby removing Europe from the center of the African reality. In this way, Afrocentricity becomes a revolutionary idea because it studies ideas, concepts, events, personalities, and political and economic processes from a standpoint of black people as subjects and not as objects, basing all knowledge on the authentic interrogation of location." http://www.asante.net/articles/1/afrocentricity/

9 For more about A Tribe Called Quest's emphasis on Afrocentrism, see the March 24, 2016 tribute to A Tribe Called Quest by Toure in the New York Times https://www.nytimes.com/2016/03/25/opinion/the-legacy-of-a-tribe-calledquest.html

Hess, Juliet, and Brent C. Talbot. 2019. Going for broke: A talk to music teachers. Action, Criticism, and Theory for Music Education 18 (1): 89-116. doi:10.22176/act18.1.89 
${ }^{10}$ On November 13, 2015, eight coordinated terrorist attacks by three teams over the span of 33 minutes killed 130 people and injured hundreds of others in Paris. These included three attacks at a national stadium, four at different restaurants across the city, and one at a concert venue. ISIS claimed responsibility for the attacks. See these two articles for further explanation and a timeline of the events: https://www.britannica.com/event/Paris-attacks-of-2015 https://www.nytimes.com/interactive/2015/11/13/world/europe/parisshooting-attacks.html

${ }^{11}$ In response to the attacks, then Republican primary contender Donald Trump proposed a temporary ban on all Muslims entering the country (Panduranga et al. 2017). Four months prior, he promised his rally attendees that he would "build a great, great wall” separating the U.S./Mexico border (Nixon and Qiu 2018).

${ }^{12}$ In the live Grammy performance, A Tribe Called Quest included more identities than those in the recorded track.

13 We recommend readers watch the video of the live Grammy performance embedded here: http://www.slate.com/blogs/browbeat/2017/02/13/a_tribe_called_quest_show ed_the_grammys_how_political_statements_are_done.html

14 The travel ban has since been upheld in the Supreme Court (Liptak \& Shear, 2018). Read more here: https://www.nytimes.com/2018/o6/26/us/politics/supreme-court-trumptravel-ban.html

${ }^{15}$ see above endnote.

${ }_{16}$ We recognize this is not a new idea. Such topics were at the forefront of the Tanglewood I and II symposia and many scholars in the past 25 years have subsequently written about this need (see Regelski 2016; Elliott and Silverman, 2015; Goble 2010; Kratus 2007, 2016; Talbot 2018, to name just a few). Unfortunately, this idea has not yet been actualized and bears repeating. As such, we urge music educators to accept the challenge as stated by numerous scholars (past and present) to "go for broke."

Hess, Juliet, and Brent C. Talbot. 2019. Going for broke: A talk to music teachers. Action, Criticism, and Theory for Music Education 18 (1): 89-116. doi:10.22176/act18.1.89 
17 Teachers have faced discipline and censure for the use of musics deemed "profane" in the classroom. See Willis (2017) for example.

Hess, Juliet, and Brent C. Talbot. 2019. Going for broke: A talk to music teachers. Action, Criticism, and Theory for Music Education 18 (1): 89-116. doi:10.22176/act18.1.89 